\title{
Structure of cryptic reef fish assemblages: relationships with habitat characteristics and predator density
}

\author{
Trevor J. Willis ${ }^{1,2,3, *}$, Marti J. Anderson ${ }^{2}$ \\ ${ }^{1}$ Leigh Marine Laboratory, University of Auckland, PO Box 349, Warkworth, New Zealand \\ ${ }^{2}$ Department of Statistics, University of Auckland, Private Bag 92019, Auckland, New Zealand \\ ${ }^{3}$ Present address: Centro Interdipartimentale di Ricerca per le Scienze Ambientali di Ravenna, Università di Bologna, \\ Via Tombesi dall'Ova 55, 48100 Ravenna, Italy
}

\begin{abstract}
Cryptic fish assemblages on temperate rocky reefs in New Zealand are among the most diverse in the world, yet very little is known regarding ecological processes that may affect their density and diversity. The potential effects of reef structural complexity, kelp density, and the increased density of predatory fish on assemblages of small, cryptic reef fishes were examined in northeastern New Zealand. Sampling was conducted in replicated areas inside and outside a marine reserve, where differential densities of predatory fishes were known to occur. There was a strong positive correlation between substratum complexity and the density and diversity of cryptic fish assemblages. While the more common fish species occurred in both kelp Ecklonia radiata forest habitat and rocky reefs grazed by urchins, the composition of less abundant species differed between these 2 habitats. Assemblages in kelp forests were more variable than those in urchin barrens. The sites inside the marine reserve contained, on average, lower densities of cryptic fishes than sites outside the reserve, which might be explained by effects of predators. The effect of the marine reserve appeared to be strongest in the kelp forest habitat, with relatively little difference seen between reserve and non-reserve assemblages in unvegetated habitats. If these observed patterns are found to be consistent at other reserves and at other times, they imply that removal of predators by fishing may have large-scale positive effects on assemblages of small cryptic reef fishes.
\end{abstract}

KEY WORDS: Assemblage structure $\cdot$ Habitat complexity $\cdot$ Marine reserve $\cdot$ Multivariate analysis · Predation $\cdot$ Reef fish $\cdot$ Refuge

Resale or republication not permitted without written consent of the publisher

\section{INTRODUCTION}

The relative importance of habitat complexity and its interaction with predation (from larger fish) in predicting abundances of fish is variable (e.g. Behrents 1987, Hixon \& Beets 1993, Levin \& Hay 1996, Beukers \& Jones 1997, Tupper \& Boutilier 1997, Steele 1999, Syms \& Jones 1999). For example, Ault \& Johnson (1998) found the availability of shelter and the composition of the substratum to be unrelated to the structure of assemblages on a coral reef, whereas Beukers \& Jones (1997) determined that habitat complexity and densities of predators had inter-related effects on prey species. Microhabitat can influence juvenile demography, but whether such effects are then translated to adult densities at larger spatial scales can depend on biological characteristics of adults for individual species (Tolimieri 1998).

On temperate reefs, habitat complexity is often positively correlated with the density of benthic fishes (Connell \& Jones 1991, Levin 1991, Macpherson 1994, Tupper \& Boutilier 1997). The potential effects of cover by macrophytic algae are less clear. Hindell et al. (2000) found that effects of predation on small fishes in seagrass were reduced compared to unvegetated habitats, but Levin et al. (1997) detected no difference in 
the rates of predation between sand and seagrass habitats. Algal cover can have positive effects on the density of post-settlement reef fishes (Levin \& Hay 1996); however, manipulations of kelp by Syms \& Jones (1999) indicated that removing algal cover had only weak and short-lived compositional effects on the guild of tripterygiid fishes under study.

It has often been suggested that the mechanism causing higher densities of fish in more physically complex habitats is a reduction in predation pressure, brought about by the availability of refuges (Hixon \& Beets 1993, Caley \& St John 1996). Areas with high densities of piscivores might be expected to contain relatively low densities of prey species and vice versa (Hixon \& Carr 1997, Jennings \& Polunin 1997, Prochazka 1998). Studies of predation on fishes to date have generally focused on juveniles of large reef fishes (e.g. Connell 1998), suggesting that effects on adult densities are limited to time-lagged consequences of increased juvenile mortality (Connell \& Jones 1991, Caley 1993). The suite of benthic, cryptic species (such as blennioids), by virtue of their small size, probably remains vulnerable to predation by larger piscivores throughout their life history. However, unless effects of predation are consistent and operate on relatively large reef-wide scales, detecting them might be difficult because small cryptic fishes tend to be short-lived and readily replenished (Willis \& Roberts 1996, Polivka \& Chotkowski 1998).

Increases in the density of predators appear to be indirectly responsible for changes in the extent and distribution of habitats within temperate marine reserves (Babcock et al. 1999, Tegner \& Dayton 2000, Shears \& Babcock 2002). In temperate New Zealand, increased predation on the sea urchin Evechinus chloroticus (Valenciennes) inside marine reserves has resulted in concomitant reductions in grazing on the laminarian kelp Ecklonia radiata (C. Agardh) J. Agardh. Thus, the coverage of urchin-grazed 'barrens' habitat within reserves has declined markedly, to be replaced by kelp forest (Babcock et al. 1999, Shears $\&$ Babcock 2002, 2003). Changes in predatory fish densities and changes in the distribution and extent of kelp forest habitat in marine reserves may each have important effects on the suite of cryptic fishes common on New Zealand reefs (Paulin \& Roberts 1992, Syms 1995, Willis \& Roberts 1996). Here, we use the term 'cryptic fishes' to refer to the assemblage of small, benthic fishes that have cryptic colouration, behaviour and/or occur in cryptic habitats (e.g. in crevices, under overhangs, etc.) and are thus usually difficult to reliably detect. Cryptic species usually exhibit a high degree of endemism (Paulin \& Roberts 1993), and in New Zealand are dominated by the highly diverse triplefins (Tripterygiidae) and clingfishes (Gobiesocidae). Cur- rently, there are no known studies of the potential indirect effects of marine reserves on these cryptic fish assemblages, although direct, predation-related effects have been suggested (Macpherson 1994, Sasal et al. 1996, Prochazka 1998, Tupper \& Juanes 1999).

Numerically dominant fish predators on New Zealand reefs (snapper Pagrus auratus: Sparidae; and blue cod Parapercis colias: Pinguipedidae) attain significantly higher densities within marine reserves than in fished areas (Willis \& Babcock 2000, Willis et al. 2000, 2003, Davidson 2001). In this study, we used a marine reserve as a large-scale manipulation of predator density. Two questions were of primary interest in the present mensurative study: (1) do cryptic fish assemblages change with increased densities of predators inside versus outside a marine reserve? and (2) is there a relationship between the structure of cryptic fish assemblages and either the topographic complexity of the substratum or macrophyte cover?

\section{MATERIALS AND METHODS}

Study area and sampling design. The sampling design included 2 factors: (1) 'Habitat' with 2 levels: laminarian kelp Ecklonia radiata forest (mean depth = $8.7 \pm 0.5[\mathrm{SE}] \mathrm{m})$, and 'urchin barrens', which are areas of reef devoid of macrophytes and dominated by the urchin Evechinus chloroticus (mean depth $=7.0 \pm$ $0.4 \mathrm{~m}$ ), and (2) marine reserve 'Status' with 2 levels: inside the marine reserve (high densities of the predators Parapercis colias and Pagrus auratus) and outside the marine reserve (low densities of predators). Sampling was done between 15 November 1999 and 10 February 2000 (austral summer) in and adjacent to the Cape Rodney-Okakari Point Marine Reserve in northeastern New Zealand $\left(36^{\circ} 17^{\prime} \mathrm{S}, 174^{\circ} 48^{\prime} \mathrm{E}\right.$, Fig. 1). Three replicate $9 \mathrm{~m}^{2}$ plots were censused within each of the 2 habitats at 2 reserve locations (Alphabet Bay and Tabletop) and 2 non-reserve locations (V-Bay and Nordic Reef). Treatments were interspersed in time to avoid temporal confounding due to settlement events or seasonal changes in predator density. Non-reserve samples were taken from outside the reserve in only 1 direction (Fig. 1) for 2 main reasons. First, the bedrock type changes from greywacke to sandstone northwest of Alphabet Bay, and because each sample took $>3 \mathrm{~h}$ to complete, we did not have the resources to include different types of rocky substratum as a separate factor in the design. Second, all urchin barrens habitat had disappeared from the northern end of the reserve before this programme began (Shears \& Babcock 2003), so we could not balance the sampling design on that side with respect to habitat in any case. Densities of predators at the 4 locations were deter- 
mined by a combination of visual census from 2 surveys in $2000\left(25 \times 5 \mathrm{~m}\right.$ transects, $\mathrm{n}=18$ location $^{-1}$ survey $^{-1}$ ), and baited underwater video (Willis \& Babcock 2000) from 5 surveys conducted between 1997 and 2000 ( $\mathrm{n}=4$ location $^{-1}$ survey $^{-1}$ ).

Sampling methods. Cryptic fish assemblages were censused in $3 \times 3 \mathrm{~m}\left(9 \mathrm{~m}^{2}\right)$ plots using the piscicide rotenone. Visual census techniques can underestimate the density of some species and fail to detect others, particularly burrowers and those species that inhabit holes and caves in the reef (Christenson \& Winterbottom 1981, Brock 1982, Ackerman \& Bellwood 2000, Willis 2001). For sampling, each plot was enclosed by a $3 \times 3 \mathrm{~m}$ square cage with $1 \mathrm{~m}$ high walls, and covered by $1.0 \mathrm{~mm}$ mesh. The mesh of the cage was weighted at its base with galvanised chain so that it could be moulded to the substratum. A $15 \mathrm{~kg}$ weight was placed to define each of the corners of the plot, and 2 corners of the cage wall were clipped to 2 adjacent weights. The other 2 corners of the net were then lifted and swum into position, which enabled the walls to be set in place with minimum disturbance to the plot. The roof section was then attached by means of continuous velcro strips. Finally, small floats were attached to the 4 corners to prevent the net from sagging. Rotenone (200 g of $7 \%$ rotenone powder mixed to a paste with seawater and a small amount of detergent, to act as a surfactant) was distributed throughout the cage from under the side walls and through the velcro connection between roof and walls, which was then immediately resealed.

After the rotenone was released, 2 divers continuously patrolled the circumference up to $2 \mathrm{~m}$ from the

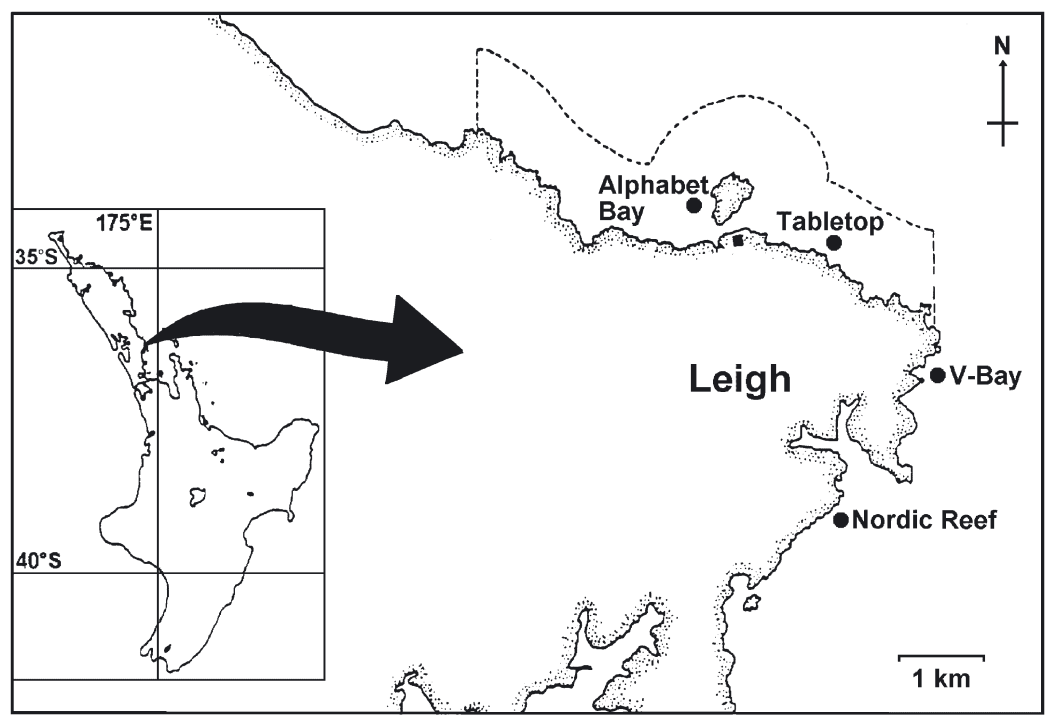

Fig. 1. Location of Cape Rodney-Okakari Point Marine Reserve in northeastern New Zealand with locations of sampling locations. Dashed line indicates reserve boundary enclosure, to prevent predators (mostly Parapercis colias, Pagrus auratus, Notolabrus celidotus, and N. fucicola) from accessing any small gaps at the base, and to capture any escaping fish. Rotenone affects different species at different rates, with tripterygiids usually taking 5 to $10 \mathrm{~min}$ to succumb to its effects, whereas gobiids and plesiopids may take $>40 \mathrm{~min}$ ( $\mathrm{T}$. J. Willis pers. obs.). Therefore, the divers patrolled outside the net for a minimum of $60 \mathrm{~min}$, before 1 diver entered the net to complete the collection. The floor of the plot was intensively searched, with all interstices examined to ensure a complete census. All fish collected were identified following Paulin \& Roberts (1992) and Paulin (1995).

Before the enclosure was disassembled, stipes of Ecklonia radiata were counted in the plot, and the complexity of the substratum estimated using the 'chain and tape' method (e.g. Connell \& Jones 1991, McCormick 1994). This was measured by the ratio of the length of a flexible measuring tape contoured to the bottom, versus the linear distance between the tape end-points. The index of complexity for each plot was calculated as the mean of 2 ratios, measured diagonally across each plot.

Statistical analyses. The response of the multivariate cryptic fish assemblage to the 2-factor mensurative sampling design was examined using non-parametric multivariate analysis of variance (NP-MANOVA, Anderson 2001a). There were 31 species variables, each transformed to $y^{\prime}=\sqrt{y}$ ' to retain information regarding relative abundances but to reduce differences in scale among the variables (e.g. Clarke \& Green 1988). Bray-Curtis dissimilarities were calculated between all pairs of observations for ensuing analyses (Bray \& Curtis 1957). In addition, non-parametric tests for differences in multivariate dispersion for the 2-factor design were done (using the program NPDisp, Anderson 2000). For NP-MANOVA and NPDisp, we used 4999 unrestricted random permutations of the raw data (Anderson 2001b).

Non-metric multidimensional scaling (MDS, Kruskal \& Wish 1978) was used to visualize multivariate patterns among plots on the basis of the BrayCurtis dissimilarities. MDS is an unconstrained ordination method and thus allows patterns in overall dispersion and potential differences in relative within-group dispersions to be visualized. In contrast, a constrained ordination can be used to visualize multivariate patterns with respect to 
particular hypotheses. Thus, we also did constrained ordinations, using a new method called canonical analysis of principal coordinates or CAP (Anderson \& Willis 2003, Anderson \& Robinson 2003). This method is simply a traditional canonical discriminant analysis (if the hypothesis concerns group differences) or a canonical correlation analysis (if the hypothesis concerns continuous predictors) on a subset of coordinate axes from a metric (classical) multi-dimensional scaling (Gower 1966, Anderson \& Willis 2003). Separate canonical analyses were done to visualize, in each case, the potential relationship between multivariate variation in cryptic fish assemblages and each of the following: (i) marine reserve Status (non-reserve vs reserve); (ii) Habitat (kelp forest vs urchin barrens); (iii) complexity of the substratum and (iv) density of kelp. The canonical correlations in each case were tested using 4999 unrestricted random permutations of the raw data.

The more abundant species variables and those that obtained a correlation of $|r|>0.20$ with either of the canonical discriminant axes (Status or Habitat) were then investigated individually with univariate analysis of variance (ANOVA). ANOVA was also done on the total number of fish and on the total number of species. Less abundant species were analysed in terms of their frequencies of occurrence using the chi-squared test statistic. No univariate analyses were done for species that occurred in fewer than 3 plots.

The assumption of normality was checked using the Weisberg-Bingham test (1972) and the assumption of homogeneity of variances was checked using Levene's test (1960). All variables except for Forsterygion lapillum conformed to the assumption of homogeneity of variances required for analysis $(p>0.05)$. For F. lapillum, the data were right-skew, but a transformation to $y^{\prime}=\ln (y+1)$ that removed significant heterogeneity did not change the outcome of the analysis, so the analysis of raw data was retained for ease of interpretation. Several of the variables (Ruanoho whero and the total number of fish) showed significant nonnormality. Thus, ANOVAs were done for all variables using 9999 unrestricted random permutations of the observations (e.g. Manly 1997, Anderson 2001b). Permutation tests have comparable power to normal-theory tests when data are approximately normal, but also maintain Type I error and have good power when data are non-normal. Pair-wise comparisons for all combinations of Status $\times$ Habitat were also done using $t$-tests and 9999 permutations of the raw data.

To further investigate the potential relationship between the structural complexity of the habitat and variation in cryptic fish assemblages, we also tested for significant correlations of the complexity index with individual species variables (square-root transformed), the total number of species and the total number of fish. We also tested for systematic changes in the habitat structural complexity inside versus outside the reserve, which might confound interpretation of any effects of Status, using non-parametric multivariate regression (McArdle \& Anderson 2001) of the assemblage data versus Status, treating complexity as a covariable. The analysis was done using the DISTLM computer program (Anderson 2002) with 4999 permutations under a reduced model (Anderson 2001b).

\section{RESULTS}

\section{Density of predators}

There were significantly higher densities of snapper (Pagrus auratus, $F_{1,77}=60.95, \mathrm{p}<0.001$ ), blue cod (Parapercis colias, $\left.F_{1,77}=7.51, \mathrm{p}=0.007\right)$ and banded wrasse (Notolabrus fucicola, $F_{1,147}=5.62, \mathrm{p}=0.019$ ) at the reserve locations than at non-reserve locations (Fig. 2). This is consistent with previously published results (Willis et al. 2000, 2003). The density of another potential predator and competitor of triplefins, the spotty Notolabrus celidotus, was variable at the location level but did not differ significantly between reserve and non-reserve areas $\left(F_{1,147}=0.61, \mathrm{p}=0.44\right.$, Fig. 2). Other possible piscivores (e.g. Zeus faber) were present in the surveys but were too infrequent for meaningful comparison.

\section{Effects of marine reserve status and habitat}

Cryptic fish assemblages differed significantly inside versus outside the marine reserve, and in kelp forests compared to urchin barrens, and there was no significant interaction between reserve Status and Habitat (Table 1). Cryptic fish assemblages in kelp forest habitats exhibited more multivariate variability than assemblages in urchin barrens (Fig. 3, Table 2). The average within-group dissimilarity for the assemblages

Table 1. Non-parametric multivariate analysis of variance (NPMANOVA) on the basis of Bray-Curtis dissimilarities for cryptic fish assemblages (31 species) after square-root transformation

\begin{tabular}{|lcrrrc|}
\hline Source & df & \multicolumn{1}{c}{ SS } & MS & \multicolumn{1}{c|}{$F$} & $\mathrm{p}$ \\
\hline Status & 1 & 4051.9008 & 4051.9008 & 2.9743 & 0.0038 \\
Habitat & 1 & 3470.9434 & 3470.9434 & 2.5478 & 0.0134 \\
Status $\times$ Habitat & 1 & 977.5880 & 977.5880 & 0.7176 & 0.7058 \\
Residual & 20 & 27246.2071 & 1362.3104 & & \\
Total & 23 & 35746.6392 & & & \\
\hline
\end{tabular}


Table 2. Non-parametric tests of multivariate dispersion (NPDisp) on the basis of Bray-Curtis dissimilarities for cryptic fish assemblages (31 species) after square-root transformation

\begin{tabular}{|lcrrrc|}
\hline Source & df & \multicolumn{1}{c}{ SS } & \multicolumn{1}{c|}{ MS } & \multicolumn{1}{c|}{$F$} & $\mathrm{p}$ \\
\hline Status & 1 & 17.1821 & 17.1821 & 0.2105 & 0.6500 \\
Habitat & 1 & 471.4491 & 471.4491 & 5.7754 & 0.0242 \\
Status $\times$ Habitat & 1 & 0.4215 & 0.4215 & 0.0052 & 0.9432 \\
Residual & 20 & 1632.6100 & 81.6305 & & \\
Total & 23 & 2121.6626 & & & \\
\hline
\end{tabular}
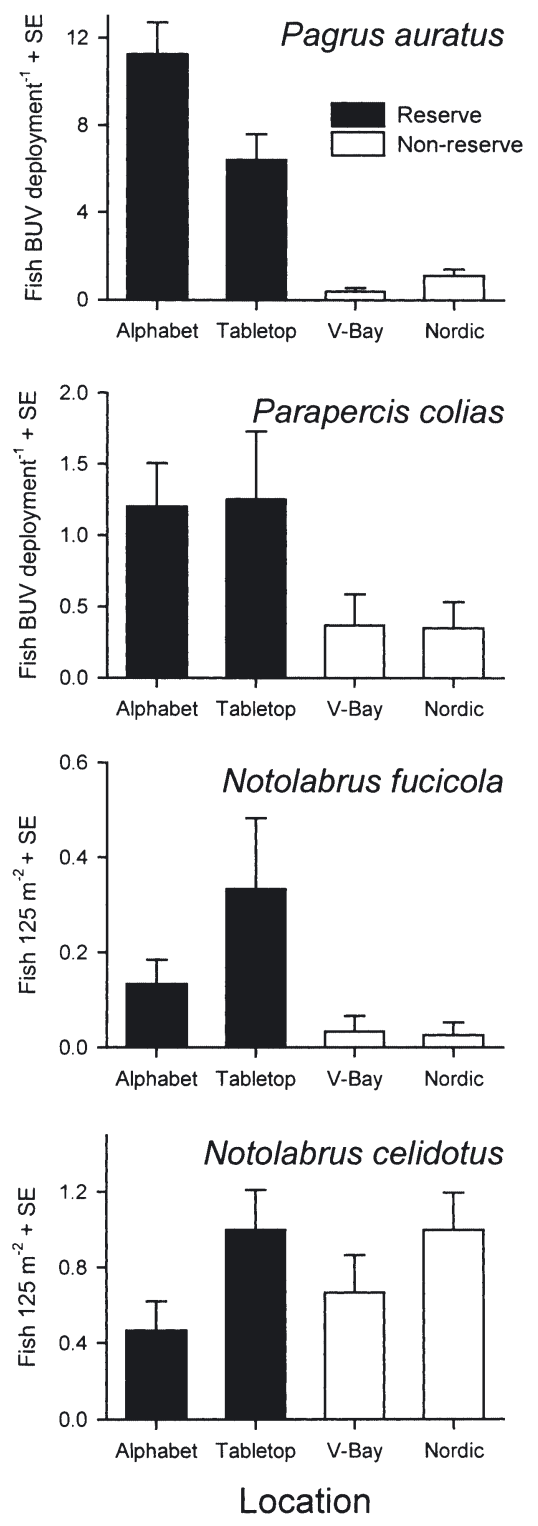

Fig. 2. Mean density (+1 SE) of 4 abundant predatory reef fishes (Pagrus auratus, Parapercis colias, Notolabrus fucicola, and Notolabrus celidotus) at reserve and non-reserve locations, taken from either baited underwater video (BUV) or visual census surveys in kelp forests was $59.6 \%$, compared to only $44.2 \%$ in urchin barrens.

The significant differences found by NP-MANOVA were not shown clearly in the MDS plot (Fig. 3). The CAP analysis, however, showed a significant effect of Habitat (Fig. 4), with a squared canonical correlation of $\delta^{2}=0.521(\mathrm{p}=0.0074)$. There was also a significant effect of marine reserve Status (Fig. $4, \delta^{2}=0.375$, $\mathrm{p}=0.0058$ ). The canonical axes corresponding to the 2 main effects (Fig. 4) clearly separated the cryptic fish assemblages in non-reserve kelp forest habitats (black triangles) from reserve kelp forest habitats (open triangles), and non-reserve urchin barrens (black circles) from reserve urchin barrens (open circles). The kelp forest assemblage was also separated from urchin barrens within the reserve, but the habitats were less distinct outside the reserve. The relative distinctiveness of the assemblages is also demonstrated well by the differences in the leave-one-out allocation success from the CAP analysis (Table 3; Lachenbruch \& Mickey 1968, Anderson \& Willis 2003). Assemblages in kelp forests were much more variable and harder to predict (i.e. had a greater misclassification error), than did assemblages in urchin barrens habitat (Table 3).

The correlations of individual species with the canonical axis corresponding to habitat effects are shown in Table 4, where positive correlations indicate an association with kelp forests and negative correlations indicate an association with urchin barrens. Species associated with kelp forests included several species known to have biological associations with kelp, including the clingfish Gastrocyathus gracilis and Haplocylix littoreus. The blue-eyed triplefin Notoclinops segmentatus and the slender roughy Optivus elongatus were also associated with kelp forest habitat. Those species associated with urchin barrens included many of the more abundant triplefins (2 species of Forsterygion and Ruanoho whero) and the crested blenny Parablennius laticlavius.

The correlations of individual species with the canonical axis corresponding to marine reserve status (Fig. 4) indicated many species associated with sites outside the reserve, with Dellichthys morelandi, Trachelochismus melobesia, Forsterygion lapillum and Pseudophycis breviuscula all having correlations greater than 0.39. Only 1 species, Bidenichthys beeblebroxi, was associated with reserve sites (Table 5).

Most of the species in the cryptic fish assemblages occurred too infrequently even to analyse their frequencies statistically, let alone their numbers (Table 6). However, 1 species, juvenile Notolabrus celidotus, occurred significantly more frequently in kelp forest than in urchin barrens habitat (Table 6, $\chi^{2}=4.80$, $\mathrm{p}=0.028$ ). Importantly, there were significantly fewer occurrences of Pseudophycis breviuscula and of Trach- 
Table 3. Results of canonical analysis of principal coordinates (CAP) analysis examining the effects of reserve Status, Habitat, substratum complexity and kelp density on the cryptic fish assemblages. $\%$ Var $=$ percentage of the total variation explained by the first $m$ principal coordinate axes. Allocation success = percentage of points correctly allocated into each group. $\delta^{2}=$ squared canonical correlation

\begin{tabular}{|c|c|c|c|c|c|c|c|}
\hline \multirow[t]{2}{*}{ Factor } & \multirow[t]{2}{*}{$m$} & \multirow[t]{2}{*}{$\% \operatorname{Var}$} & \multicolumn{3}{|c|}{ — Allocation success (\%) } & \multirow[t]{2}{*}{$\delta^{2}$} & \multirow[t]{2}{*}{$\mathrm{p}$} \\
\hline & & & Group 1 & Group 2 & Total & & \\
\hline Status & 4 & 69.24 & 91.67 (Reserve) & 66.67 (Non-reserve) & 79.17 & 0.375 & 0.006 \\
\hline Habitat & 5 & 75.54 & 16.67 (Kelp forest) & 100.00 (Urchin barrens) & 58.33 & 0.521 & 0.007 \\
\hline Complexity & 5 & 76.54 & & & & 0.486 & 0.020 \\
\hline Kelp density & 3 & 60.60 & & & & 0.519 & 0.002 \\
\hline
\end{tabular}

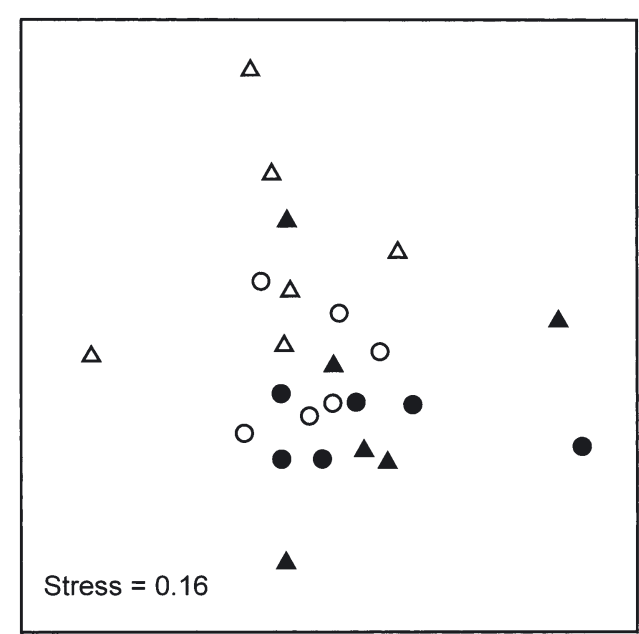

A Non-reserve, kelp forest

- Non-reserve, urchin barrens

$\Delta \quad$ Reserve, kelp forest

O Reserve, urchin barrens

Fig. 3. Non-metric multidimensional scaling (MDS) plot of assemblages of cryptic fish in each combination of reserve versus non-reserve locations and kelp versus urchin barrens habitats

elochismus melobesia at reserve sites than at nonreserve sites (Table $6, \chi^{2}=4.44, p=0.035$ in each case). Furthermore, of the 9 species that only occurred once in the data set, 7 of these occurred in non-reserve sites (Table 6).

Table 4. Correlation coefficients for individual species $(|r|>0.20)$ with the canonical axis for effects of Habitat. Species variables were transformed to square roots. A positive correlation indicates association with kelp forest, while a negative correlation indicates an association with urchin barrens habitat

\begin{tabular}{|llll|}
\hline \multicolumn{2}{l}{ Positive correlation (kelp forest) } & \multicolumn{2}{l|}{ Negative correlation (urchin barrens) } \\
\hline Gastrocyathus gracilis & 0.4353 & Forsterygion lapillum & -0.8615 \\
Bidenichthys beeblebroxi & 0.4127 & Forsterygion varium & -0.3935 \\
Optivus elongatus & 0.4003 & Parablennius laticlavius & -0.3609 \\
Notoclinops segmentatus & 0.3531 & Trachelochismus melobesia & -0.3150 \\
Acanthoclinus rua & 0.3045 & Ruanoho whero & -0.2321 \\
Haplocylix littoreus & 0.2268 & Brosmodorsalis persicinus & -0.2022 \\
\hline
\end{tabular}

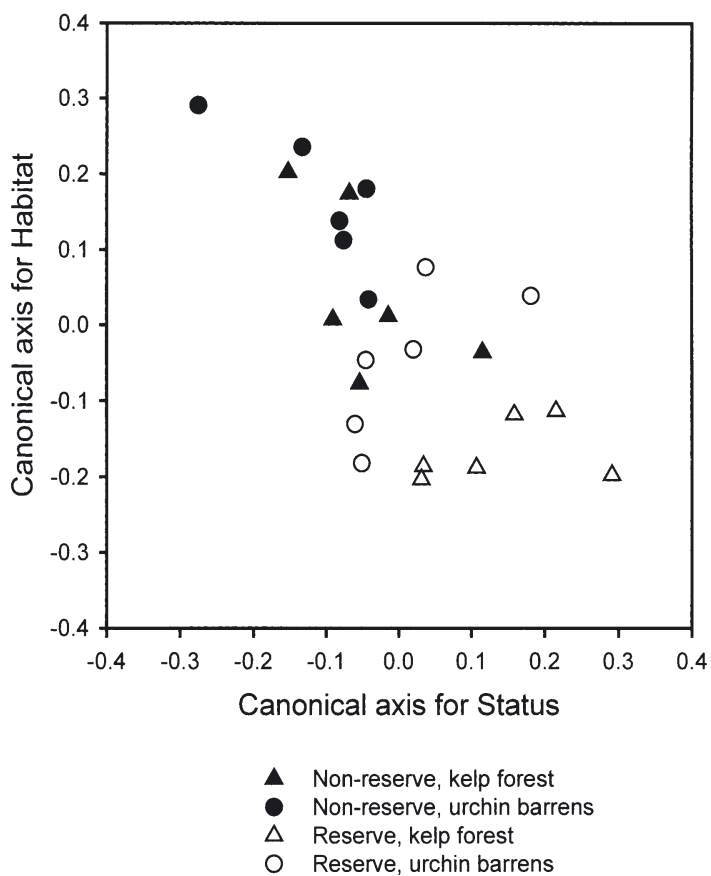

Fig. 4. Two-dimensional scatter plot of the canonical axes for habitat and marine reserve status

There were significantly greater numbers of the triplefin Forsterygion lapillum in urchin barrens than in kelp forest habitats (Table 7, Fig. 5a). This species and Dellichthys morelandi were also found in significantly greater numbers at non-reserve sites compared to sites inside the reserve (Table 7 , Fig. 5a,b). The 2 triplefin species Forsterygion varium and Ruanoho whero showed a pattern of fewer numbers, on average, inside the marine reserve, but only in kelp forests (Fig. 5c,d), although this pattern was not statistically significant (Table 7). Overall, there were significantly fewer total numbers of cryptic fish and fewer numbers of cryptic fish species (i.e. diversity) at reserve sites than at nonreserve sites (Fig. 5e,f, Table 7). On 
Table 5. Correlation coefficients for individual species $(|r|>0.20)$ with the canonical axis for effects of Status (reserve vs non-reserve). Species were transformed to square root. A positive correlation indicates association with nonreserve locations, while a negative correlation indicates an association with reserve locations

\begin{tabular}{|lll|}
\hline \multicolumn{2}{l}{ Positive correlation (non-reserve) } & Negative correlation (reserve) \\
\hline Dellichthys morelandi & 0.7424 & Bidenichthys beeblebroxi -0.3201 \\
Trachelochismus melobesia & 0.5504 & \\
Forsterygion lapillum & 0.4928 & \\
Pseudophycis breviuscula & 0.3961 & \\
Conger wilsoni & 0.3133 & \\
Ruanoho whero & 0.3063 & \\
Acanthoclinus rua & 0.2877 & \\
Acanthoclinus marilynae & 0.2778 & \\
Brosmodorsalis persicinus & 0.2308 \\
\hline
\end{tabular}
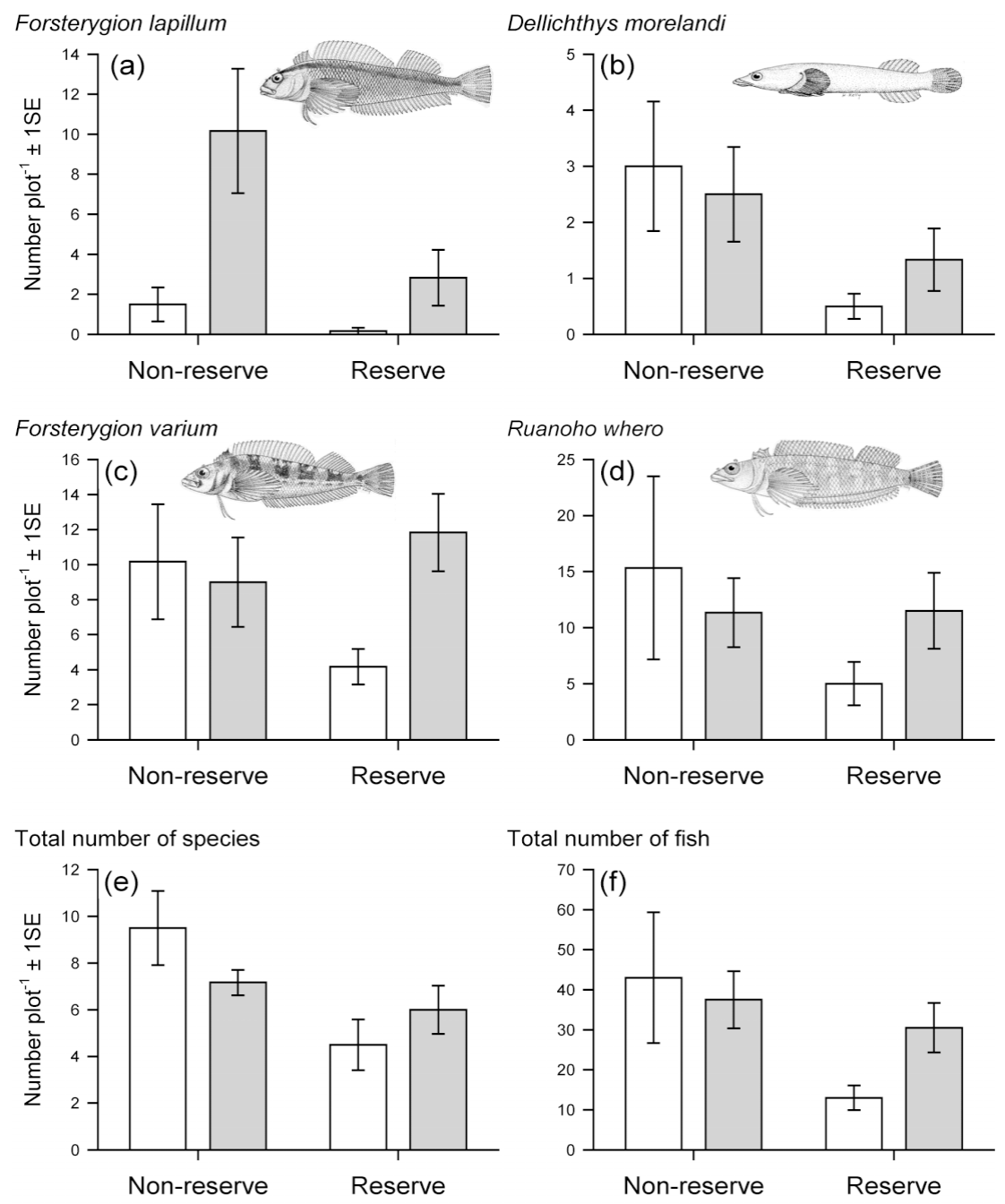

Total number of fish

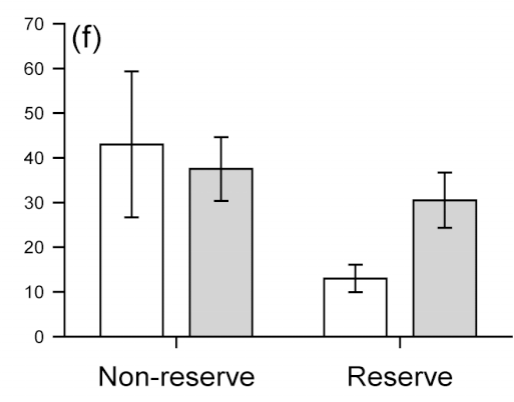

Kelp forest average, these effects appeared more marked for the kelp forest than for the urchin barrens habitat (Fig. 5), although there was not a significant Status $\times$ Habitat interaction for any of these variables (Table 7) or for the multivariate data (Table 1).

Although the Status $\times$ Habitat interaction term for individual variables was not generally statistically significant (Table 7), this may have been due to a lack of power. Thus, we considered it was worth investigating individual pair-wise comparisons, as there was, nevertheless, a general pattern of smaller average numbers of fish in kelp forests inside reserves compared to any other combination of treatments for Dellichthys morelandi, Ruanoho whero, Forsterygion varium, and the total number of species (Fig. 5). This pattern was statistically significant, according to pairwise comparisons (unadjusted $\mathrm{p}<0.05$ ), for the total number of fish (Table 8). There was also a significantly greater number of species, on average, outside marine reserves compared to inside marine reserves for kelp forests, but no significant effect of Status on richness for urchin barrens habitats (Table 8).

\section{Effects of substratum complexity and kelp density}

Sample plots of varying substratum complexity (as measured by the average chain-and-tape ratio) were found in all combinations of Status and Habitat. Thus, the index of complexity was not related in any systematic way to the effects of Habitat or marine reserve Status. Multivariate multiple regression, with complexity included as a covariable, found that the difference between reserve and non-reserve fish assemblages was still significant $\left(F_{1,21}=2.291, \mathrm{p}=0.025\right)$. Therefore, differences between assemblages inside versus outside the reserve were not due to differences in complexity between the reserve and non-reserve sites.
Fig. 5. Mean ( $\pm 1 \mathrm{SE})$ numbers of (a) Forsterygion lapillum, (b) Dellichthys morelandi, (c) Forsterygion varium, (d) Ruanoho whero, (e) species and (f) all fish in non-reserve and reserve locations in either kelp forest or urchin barrens habitat $(n=6)$ 

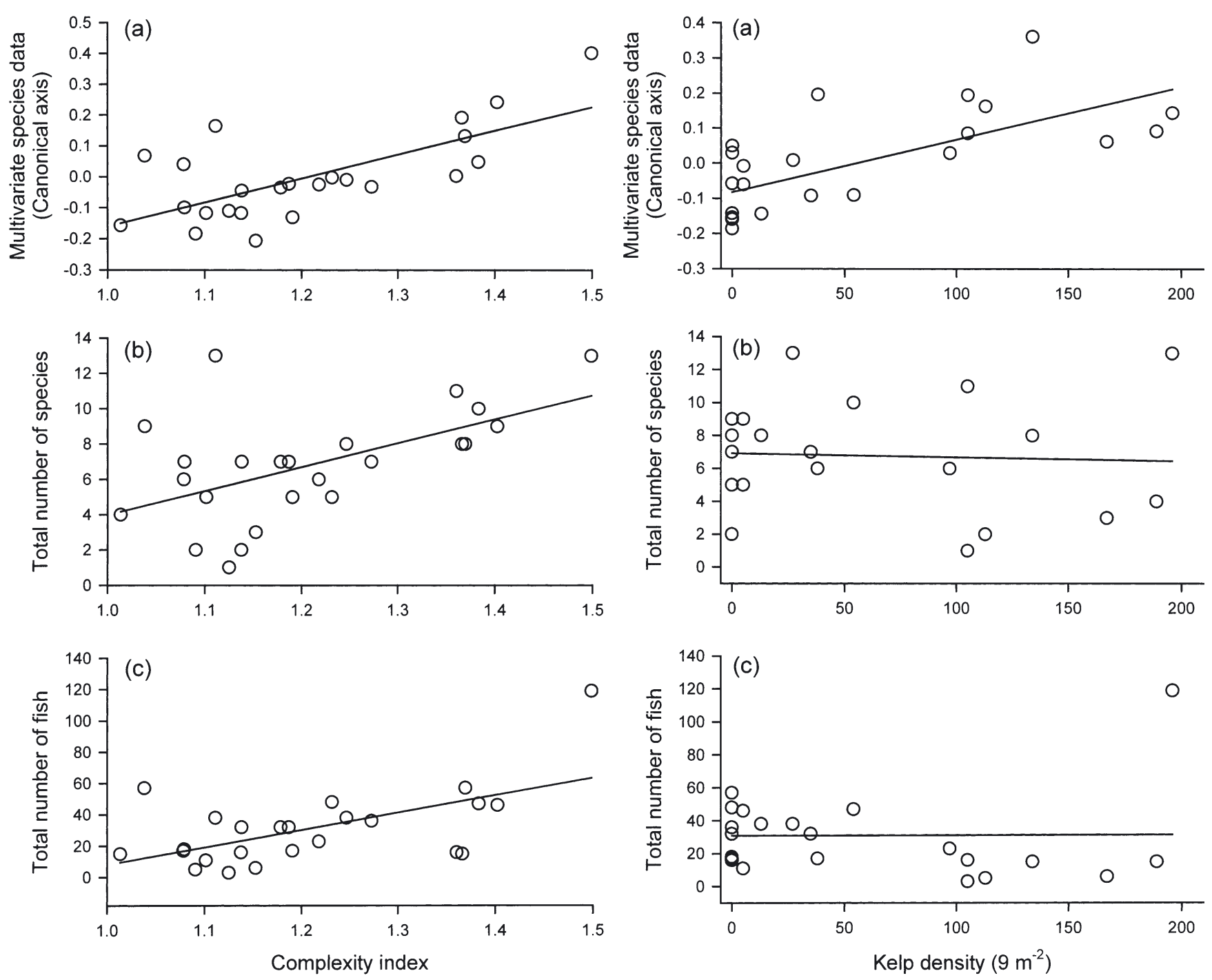

Fig. 6. Relationships between structural complexity (average chain-and-tape measure) and (a) multivariate cryptic fish assemblages (i.e. the canonical axis), (b) total number of species and (c) total number of fish

Fig. 7. Relationships between kelp density (plants per $9 \mathrm{~m}^{2}$ ) and (a) multivariate cryptic fish assemblages (i.e. the canonical axis), (b) total number of species and (c) total number of fish

There was a significant relationship between structural complexity and cryptic fish assemblage structure (Table 3, Fig. 6a). The density of several individual species was significantly correlated with structural complexity, including hole and cave dwellers such as the northern bastard cod Pseudophycis breviuscula, the slender roughy Optivus elongatus, and scorpionfish Scorpaena papillosus (Table 9). Other species were also significantly correlated with complexity, although in these cases the relationship was apparently caused by the plot with the highest index for complexity (1.499) having the greatest number of individuals (119). Removal of this high leverage point made the relationship non-significant for Acanthoclinus marilynae, and the triplefins Ruanoho whero,

Forsterygion varium and Notoclinops segmentatus (Table 9).

There was a significant relationship between the total number of species and structural complexity (Fig. 6b, $\mathrm{r}^{2}=0.307, \mathrm{p}=0.005$ ) and between the total number of fish and structural complexity (Fig. 6c, $\mathrm{r}^{2}=0.341, \mathrm{p}=0.003$ ). However, the latter relationship was also influenced by the plot with the highest index for complexity. Removing this high leverage point weakened the relationship substantially $\left(\mathrm{r}^{2}=0.150\right.$, $p=0.068)$. In contrast, the relationship between diversity and complexity was a pattern that remained statistically significant even when the plot with highest complexity was removed (Fig. 6b, and $r^{2}=0.198$, $\mathrm{p}=0.035)$. 
Table 6. Frequencies of occurrence of species in each of the categories reserve Status and Habitat

\begin{tabular}{|c|c|c|c|c|c|}
\hline \multirow[t]{2}{*}{ Species } & \multirow[t]{2}{*}{ Family } & \multicolumn{2}{|c|}{ Status } & \multicolumn{2}{|c|}{ Habitat } \\
\hline & & Non-reserve & Reserve & Kelp forest & Urchin barrens \\
\hline Ruanoho whero & Tripterygiidae & 12 & 11 & 11 & 12 \\
\hline Forsterygion varium & Tripterygiidae & 11 & 12 & 12 & 11 \\
\hline Dellichthys morelandi & Gobiesocidae & 9 & 7 & 8 & 8 \\
\hline Forsterygion lapillum & Tripterygiidae & 9 & 5 & 4 & 10 \\
\hline Pseudophycis breviuscula & Moridae & 7 & 2 & 4 & 5 \\
\hline Trachelochismus melobesia & Gobiesocidae & 7 & 2 & 3 & 6 \\
\hline Acanthoclinus marilynae & Plesiopidae & 5 & 3 & 5 & 3 \\
\hline Notoclinops segmentatus & Tripterygiidae & 3 & 3 & 4 & 2 \\
\hline Scorpaena papillosus & Scorpaenidae & 2 & 3 & 2 & 3 \\
\hline Brosmodorsalis persicinus & Bythitidae & 4 & 1 & 3 & 2 \\
\hline Optivus elongatus & Trachichthyidae & 1 & 3 & 3 & 1 \\
\hline Acanthoclinus rua & Plesiopidae & 3 & 1 & 3 & 1 \\
\hline Notolabrus celidotus & Labridae & 3 & 1 & 4 & 0 \\
\hline Haplocylix littoreus & Gobiesocidae & 2 & 2 & 3 & 1 \\
\hline Notoclinus compressus & Tripterygiidae & 3 & 0 & 2 & 1 \\
\hline Dermatopsis macrodon & Bythitidae & 2 & 1 & 1 & 2 \\
\hline Conger wilsoni & Congridae & 3 & 0 & 1 & 2 \\
\hline Parablennius laticlavius & Blenniidae & 2 & 1 & 0 & 3 \\
\hline Gastrocyathus gracilis & Gobiesocidae & 1 & 1 & 2 & 0 \\
\hline Parika scaber & Monacanthidae & 2 & 0 & 2 & 0 \\
\hline Bidenichthys beeblebroxi & Bythitidae & 0 & 2 & 2 & 0 \\
\hline Conger verreauxi & Congridae & 2 & 0 & 1 & 1 \\
\hline Lotella rhacinus & Moridae & 1 & 0 & 0 & 1 \\
\hline Ruanoho decemdigitatus & Tripterygiidae & 0 & 1 & 0 & 1 \\
\hline Cristiceps aurantiacus & Clinidae & 1 & 0 & 1 & 0 \\
\hline Forsterygion malcolmi & Tripterygiidae & 1 & 0 & 0 & 1 \\
\hline Gobiopsis atrata & Gobiidae & 1 & 0 & 1 & 0 \\
\hline Hippocampus abdominalis & Syngnathidae & 1 & 0 & 1 & 0 \\
\hline Odax pullus & Odacidae & 1 & 0 & 1 & 0 \\
\hline Stigmatopora nigra & Syngnathidae & 1 & 0 & 0 & 1 \\
\hline Trachelochismus pinnulatus & Gobiesocidae & 0 & 1 & 0 & 1 \\
\hline
\end{tabular}

There was a significant canonical correlation between kelp density (number of stipes plot $^{-1}$ ) and multivariate assemblages of fishes (Table 3, Fig. $7 \mathrm{a}, \delta^{2}=0.519$, $\mathrm{p}=0.002)$, but not between kelp density and the total number of species (Fig. $7 b, r^{2}=0.002, p=0.826$ ) or the total number of fish (Fig. $7 \mathrm{c}, \mathrm{r}^{2}<0.001, \mathrm{p}=0.971$ ).

\section{DISCUSSION}

This observational study indicated that the abundance and species composition of small, cryptic reef fishes is strongly influenced by structural complexity of the reef at small spatial scales, supporting the results of the detailed study by Syms (1995). Areas of reef with higher structural complexity supported higher densities of fish and greater numbers of species. The presence of kelp forests also affected cryptic reef fish assem- blages, causing them to be more variable than in urchin barrens habitats. This variability was apparently brought about by patchiness in the distribution of species such as Gastrocyathus gracilis, Haplocylix littoreus, and juvenile Notolabrus celidotus, which are known to depend on kelp habitat (Jones 1984, Paulin \& Roberts 1992).

Our results also indicate reduced cryptic fish density and diversity within the marine reserve at Leigh

Table 7. Results of 2-factor ANOVA on 4 individual species, on the total number of species and on the total number of fish. Significant results are in bold, ${ }^{*} p<0.10$, ${ }^{* *} \mathrm{p}<0.05$

\begin{tabular}{|lcccccc|}
\hline & \multicolumn{2}{c}{ Status } & \multicolumn{2}{c}{ Habitat } & \multicolumn{2}{c|}{ Interaction } \\
& $F_{1,20}$ & $\mathrm{p}$ & $F_{1,20}$ & $\mathrm{p}$ & $F_{1,20}$ & $\mathrm{p}$ \\
\hline Forsterygion lapillum & 6.057 & $\mathbf{0 . 0 1 5}$ & & & & \\
Dellichthys morelandi & 5.576 & $\mathbf{0 . 0 2 0}^{* *}$ & 0.046 & 0.787 & 0.737 & 0.404 \\
Forsterygion varium & 0.432 & 0.515 & 1.820 & 0.188 & 3.361 & $\mathbf{0 . 0 7 9}^{*}$ \\
Ruanoho whero & 1.131 & 0.343 & 0.068 & 0.851 & 1.206 & 0.323 \\
Total no. of fish & 3.733 & $\mathbf{0 . 0 5 3}^{*}$ & 0.393 & 0.580 & 1.443 & 0.257 \\
Total no. of species & 7.514 & $\mathbf{0 . 0 1 3}^{* *}$ & 0.137 & 0.706 & 2.903 & 0.104 \\
\hline
\end{tabular}


relative to nearby fished areas where predator densities are low (Willis et al. 2000, 2003). Thus, potential indirect effects of establishing a marine reserve in temperate New Zealand may include reductions in the abundance and diversity of cryptic reef fish assemblages. It may be more useful to consider this issue from the opposing perspective, that is that removal of predators by fishing might have large-scale positive consequences for small reef-fish assemblages. Differences between reserve and non-reserve cryptic fish assemblages were primarily due to a consistently lower number of fish in marine reserve kelp habitats-despite our failure to detect a significant interaction between Status and Habitat. Only 1 common species, the common triplefin Forsterygion lapillum, could be shown to exhibit lower reserve densities in both kelp forest and urchin barrens habitats. There are caveats to this interpretation: first, our failure to detect statistically significant interactions may be a function of low statistical power in the analyses, because sample size was necessarily limited by logistic considerations. Second, we cannot differentiate effects of marine reserve status from spatial effects of individual areas with certainty, because non-reserve samples were collected from locations outside the reserve in only 1 direction. This was done to ensure continuity in the bedrock type, which changes from greywacke (on which all of our samples were collected) to sandstone part way through the reserve, resulting in large between-site differences in reef architecture. Accounting for possible effects due to bedrock type was outside the scope of this study. Although the data presented here are indicative of reserve effects, we cannot eliminate the alternative possibility that small-scale, unmeasured, variance in habitat quality explains the observed differences between reserve and non-reserve sites. Even if the effects were attributable to the reserve, this may or may not be caused by changes in densities of predatory fishes and/or changes in levels of predation. Further study is needed (e.g. simultaneous replication of several sites inside and outside of several marine reserves) to understand the mechanisms and direct or indirect effects that may have produced the observed patterns. In addition, although the use of exclusion cages has known problems (Connell 1997), manipulative experiments inside reserves will be necessary to attribute cause to observed patterns.
Jennings \& Polunin (1997) examined coral reef fish assemblages under differing levels of fishing pressure and concluded that, at the scale examined, non-target fish species did not respond to varying densities of predators. However, Tupper \& Juanes (1999) found that recruitment of juvenile grunts (Haemulidae) was reduced in a Caribbean marine reserve, and suggested that increased density of piscivores increased their mortality rate relative to fished areas. Macpherson (1994) recorded lowered densities of blennioid fishes at the Medes Islands Marine Reserve relative to fished localities in northern Spain. Similarly, Sasal et al. (1996) documented reductions in the abundance of small size classes of the goby Gobius bucchichii within Cerbére-Banyuls Marine Reserve (southern France) and attributed this to size-dependent predation. Prochazka (1998) discussed data suggestive of similar reductions in the density of small fishes at the Tsitsikamma National Park in South Africa.

Table 9. Linear regression coefficients for the density of the 10 most abundant species with substratum complexity, with associated p-values

\begin{tabular}{|lcc|}
\hline Species & $\mathrm{r}^{2}$ & $\mathrm{p}$ \\
\hline Pseudophycis breviuscula & 0.3843 & 0.001 \\
Scorpaena papillosus & 0.3294 & 0.003 \\
Optivus elongatus & 0.3002 & 0.005 \\
Acanthoclinus marilynae & 0.2998 & 0.006 \\
Ruanoho whero & 0.2581 & 0.011 \\
Notoclinops segmentatus & 0.1662 & 0.048 \\
Forsterygion varium & 0.1344 & 0.078 \\
Dellichthys morelandi & 0.0350 & 0.381 \\
Forsterygion lapillum & 0.0164 & 0.306 \\
Trachelochismus melobesia & 0.0135 & 0.588 \\
\hline
\end{tabular}


It is known that densities of snapper and blue cod are higher within the Leigh marine reserve than outside (Willis et al. 2000, 2003), but the intensity of predation on cryptic fishes by these species, if any, is unknown. Snapper are generalist feeders that have been recorded as only occasionally piscivorous (Colman 1972, N. T. Shears pers. comm.), but blennioid fishes can comprise a large component of the diet of larger blue cod (Mutch 1983). With the exception of the John Dory Zeus faber, there are no exclusively piscivorous fishes on New Zealand reefs-most species that take fish prey do so as part of a diet that includes a range of invertebrate species (Russell 1983). Other part-time demersal piscivores include the moray eels Gymnothorax spp., conger eels Conger spp., rock cod Lotella rhacinus, scorpionfishes Scorpaena spp., hiwihiwi Chironemus marmoratus, and banded wrasse Notolabrus fucicola, but their importance as predators of cryptic fishes has not been determined.

The density of cryptic fishes may have been higher in grazed habitats than in kelp forest within the reserve either because microhabitat requirements are of greater importance than is macrophyte cover from predation, or because Ecklonia radiata does not provide a refuge from predation, or both. Cryptic fishes feed primarily on epifaunal crustaceans (Paulin \& Roberts 1992, Fisher 1998) that are very abundant in coralline turfing habitats (Taylor 1998). Cover of articulated coralline turf is much more extensive in habitats devoid of large algae (Taylor 1998, Melville \& Connell 2001), so food availability may offset predation risk in unvegetated habitats. At the study sites, E. radiata stipes were ca. $1 \mathrm{~m}$ long, so the laminae probably provided no cover from predators swimming beneath the canopy. The kelp canopy may in fact assist the predators, in providing cover from which to ambush small fishes.

Increases in the cover of Ecklonia radiata forest observed in northeastern New Zealand marine reserves have been attributed to a release from grazing pressure by the urchin Evechinus chloroticus, brought about by increased predator densities (Babcock et al. 1999, Shears \& Babcock 2002, 2003). This has implications for several species. The most common demersal fish species on New Zealand reefs, the spotty Notolabrus celidotus, depends on kelp for juvenile habitat, but utilises a wider range of habitats as it grows (Jones 1984). Conversely, blue cod Parapercis colias prefer unvegetated habitats (Mutch 1983). This study illustrates that kelp forests have more speciose assemblages, though not necessarily higher densities, of cryptic fishes than areas lacking macroalgae. This implies that habitat changes at reef-wide scales caused by altering predator densities (previously referred to as 'trophic cascades', Babcock et al. 1999, Tegner \& Dayton 2000, Shears \& Babcock 2002, 2003) are likely to be felt throughout the system. Thus, cryptic fish populations may be affected by both direct (predation) and indirect (habitat change) factors within marine reserves relative to fished areas.

The data obtained in this study are mensurative rather than experimental, but provide preliminary patterns and hypotheses to be examined in greater detail with further studies. There have been several recent studies examining similar effects on single species that are components of cryptic fish assemblages (e.g. Steele 1999, Levin \& Hay 2002), but there is a need to examine multispecies assemblages in a manipulative experimental framework. This study highlights some issues that need to be considered in such experiments. These include the selection of appropriate spatial scales at which to assess habitat effects, especially since some (but not all) species may be affected by microhabitat characteristics at the scale of $\mathrm{cm}$ (e.g. Syms 1995). In this study, the use of large $\left(9 \mathrm{~m}^{2}\right)$ enclosures for sampling improved the estimation of overall density and diversity, but probably reduced our ability to detect differences in microhabitat characteristics (particularly shelter) which may have influences as great or greater than the broader habitat types used as treatments (Syms 1995, Townsend \& Tibbetts 2000). Substratum complexity appears to have large effects on the density and distribution of small fishes (Connell \& Jones 1991), but whilst macroalgal cover had compositional effects, it did not seem to greatly influence overall density.

As this and other studies have shown (e.g. Cole et al. 1990, Jennings \& Polunin 1997, Wantiez et al. 1997, Babcock et al. 1999, Edgar \& Barrett 1999, Shears \& Babcock 2002, 2003), individual species or groups of species can respond positively, negatively, or have no response at all to marine reserve protection. The lack of a positive response does not necessarily imply that marine reserves fail to 'work'. What it does suggest is that the establishment of marine reserves can have varying consequences for different components of the biota. It is therefore important that studies of marine reserve effects extend beyond the responses of exploited species and recognise the potential for direct or indirect flow-on effects to unexploited species.

Acknowledgements. Thanks to M. Gagliano, T. Langlois, and A. Rapson for their uncomplaining field assistance. C. Fisher helped with development of the sampling enclosure. Also thanks to the Department of Conservation and the Ngatiwai Trust Board for permission to sample within the marine reserve. Fish drawings (Fig. 4) by Helen Casey (neé Kelly) are reproduced from Paulin \& Roberts (1992) with permission. We appreciate the improvements to the manscript brought about by the constructive comments of R. C. Babcock, R. N. Lipcius, M. A. Samoilys, N. T. Shears, R. B. Taylor and N. Tolimieri. This work was approved by the University of Auckland Ethics Committee. T.J.W. was supported by a University of Auckland Postdoctoral Fellowship. 


\section{LITERATURE CITED}

Ackerman JL, Bellwood DR (2000) Reef fish assemblages: a re-evaluation using enclosed rotenone stations. Mar Ecol Prog Ser 206:227-237

Anderson MJ (2000) NPDisp: a FORTRAN computer program for non-parametric tests of homogeneity of multivariate dispersions (for any two-factor ANOVA design) using permutations. Department of Statistics, University of Auckland

Anderson MJ (2001a) A new method for non-parametric multivariate analysis of variance. Austral Ecol 26:32-46

Anderson MJ (2001b) Permutation tests for univariate or multivariate analysis of variance and regression. Can J Fish Aquat Sci 58:626-639

Anderson MJ (2002) DISTLM v.2: a FORTRAN computer program to calculate a distance-based multivariate analysis for a linear model. Department of Statistics, University of Auckland

Anderson MJ, Robinson J (2003) Generalised discriminant analysis based on distances. Aust NZ J Stat 45:301-318

Anderson MJ, Willis TJ (2003) Canonical analysis of principal coordinates: a useful method of constrained ordination for ecology. Ecology 84:511-525

Ault TR, Johnson CR (1998) Spatially and temporally predictable fish communities on coral reefs. Ecol Monogr 68: 25-50

Babcock RC, Kelly S, Shears NT, Walker JW, Willis TJ (1999) Changes in community structure in temperate marine reserves. Mar Ecol Prog Ser 189:125-134

Behrents KC (1987) The influence of shelter availability on recruitment and early juvenile survivorship of Lythrypnus dalli Gilbert (Pisces: Gobiidae). J Exp Mar Biol Ecol 107: 45-59

Beukers JS, Jones GP (1997) Habitat complexity modifies the impact of piscivores on a coral reef fish population. Oecologia 114:50-59

Bray JR, Curtis JT (1957) An ordination of the upland forest communities of southern Wisconsin. Ecol Monogr 27: 325-349

Brock RE (1982) A critique of the visual census method for assessing coral reef fish populations. Bull Mar Sci 32: 269-276

Caley MJ (1993) Predation, recruitment and the dynamics of communities of coral-reef fishes. Mar Biol 117:33-43

Caley MJ, St John J (1996) Refuge availability structures assemblages of tropical reef fishes. J Anim Ecol 65:414-428

Christensen MS, Winterbottom R (1981) A correction factor for, and its application to, visual censuses of littoral fish. S Afr J Zool 16:73-79

Clarke KR, Green RH (1988) Statistical design and analysis for a 'biological effects' study. Mar Ecol Prog Ser 46: $213-226$

Cole RG, Ayling TM, Creese RG (1990) Effects of marine reserve protection at Goat Island, northern New Zealand. NZ J Mar Freshw Res 24:197-210

Colman (1972) Food of snapper, Chrysophrys auratus (Forster), in the Hauraki Gulf, New Zealand. NZ J Mar Freshw Res 6:221-239

Connell SD (1997) Exclusion of predatory fish on a coral reef: the anticipation, pre-emption, and evaluation of some caging artefacts. J Exp Mar Biol Ecol 213:181-198

Connell SD (1998) Effects of predators on growth, mortality and abundance of a juvenile reef-fish: evidence from manipulations of predator and prey abundance. Mar Ecol Prog Ser 169:251-261

Connell SD, Jones GP (1991) The influence of habitat com- plexity on postrecruitment processes in a temperate reef fish population. J Exp Mar Biol Ecol 151:271-294

Davidson RJ (2001) Changes in population parameters and behaviour of blue cod (Parapercis colias: Pinguipedidae) in Long Island-Kokomohua Marine Reserve, Marlborough Sounds, New Zealand. Aquat Conserv 11:417-435

Edgar GJ, Barrett NS (1999) Effects of the declaration of marine reserves on Tasmanian reef fishes, invertebrates and plants. J Exp Mar Biol Ecol 242:107-144

Fisher CJ (1998) Population ecology of three species of triplefins (Family Tripterygiidae). MSc thesis, University of Auckland

Gower JC (1966) Some distance properties of latent root and vector methods used in multivariate analysis. Biometrika 53:325-338

Hindell JS, Jenkins GP, Keough MJ (2000) Evaluating the impact of predation by fish on the assemblage structure of fishes associated with seagrass (Heterozostera tasmanica) (Martens ex Ascherson) den Hartog, and unvegetated sand habitats. J Exp Mar Biol Ecol 255:153-174

Hixon MA, Beets JP (1993) Predation, prey refuges, and the structure of coral-reef fish assemblages. Ecol Monogr 63: 77-101

Hixon MA, Carr MH (1997) Synergistic predation, density dependence, and population regulation in marine fish. Science 277:946-949

Jennings S, Polunin NVC (1997) Impacts of predator depletion by fishing on the biomass and diversity of non-target reef fish communities. Coral Reefs 16:71-82

Jones GP (1984) The influence of habitat and behavioural interactions on the local distribution of the wrasse Pseudolabrus celidotus. Environ Biol Fish 10:43-58

Kruskal JB, Wish M (1978) Multidimensional scaling. Sage Publications, Beverly Hills

Lachenbruch PA, Mickey MR (1968) Estimation of error rates in discriminant analysis. Technometrics 10:1-11

Levene H (1960) Robust tests for equality of variances. In: Olkin I, Shurye SG, Hoeffding W, Madow WG, Mann HB (eds) Contributions to probability and statistics. Stanford University Press, Stanford, p 278-292

Levin PS (1991) Effects of microhabitat on recruitment variation in a Gulf of Maine reef fish. Mar Ecol Prog Ser 75: 183-189

Levin PS, Hay ME (1996) Responses of temperate reef fishes to alterations in algal structure and species composition. Mar Ecol Prog Ser 134:37-47

Levin PS, Hay ME (2002) Fish-seaweed association on temperate reefs: do small-scale experiments predict largescale patterns? Mar Ecol Prog Ser 232:239-246

Levin P, Petrik R, Malone J (1997) Interactive effects of habitat selection, food supply and predation on recruitment of an estuarine fish. Oecologia 112:55-63

Macpherson E (1994) Substrate utilisation in a Mediterranean littoral fish community. Mar Ecol Prog Ser 114:211-218

Manly BFJ (1997) Randomization, bootstrap and Monte Carlo methods in biology, 2nd edn. Chapman \& Hall, London

McArdle BH, Anderson MJ (2001) Fitting multivariate models to community data: a comment on distance-based redundancy analysis. Ecology 82:290-297

McCormick MI (1994) Comparison of field methods for measuring surface topography and their associations with a tropical reef fish assemblage. Mar Ecol Prog Ser 112:87-96

Melville AJ, Connell SD (2001) Experimental effects of kelp canopies on subtidal coralline algae. Aust J Ecol 26:102-108

Mutch PG (1983) Factors influencing the density and distribution of the blue cod (Parapercis colias) (Pisces: Mugiloididae). MSc thesis, University of Auckland 
Paulin CD (1995) Description of a new genus and two new species of bythitid fishes, and a redescription of Bidenichthys consobrinus (Hutton) from New Zealand. J Nat Hist 29:249-258

Paulin C, Roberts C (1992) The rockpool fishes of New Zealand. Museum of New Zealand, Wellington

Paulin CD, Roberts CD (1993) Biogeography of New Zealand rockpool fishes. In: Battershill CN, Schiel DR, Jones GP, Creese RG, MacDiarmid AB (eds) Proc 2nd Int Temperate Reef Symposium. NIWA Marine, Wellington, p 191-199

Polivka KM, Chotkowski MA (1998) Recolonization of experimentally defaunated tidepools by northeast Pacific intertidal fishes. Copeia 1998:456-462

Prochazka K (1998) Spatial and trophic partitioning in cryptic fish communities of shallow subtidal reefs in False Bay, South Africa. Environ Biol Fish 51:201-220

Russell BC (1983) The food and feeding habits of rocky reef fish of north-eastern New Zealand. NZ J Mar Freshw Res 17:121-145

Sasal P, Faliex E, Morand S (1996) Population structure of Gobius bucchichii in a Mediterranean marine reserve and in an unprotected area. J Fish Biol 49:352-356

Shears NT, Babcock RC (2002) Marine reserves demonstrate top-down control of community structure on temperate reefs. Oecologia 132:131-142

Shears NT, Babcock RC (2003) Continuing trophic cascade effects after 25 years of no-take marine reserve protection. Mar Ecol Prog Ser 246:1-16

Steele MA (1999) Effects of shelter and predators on reef fishes. J Exp Mar Biol Ecol 233:65-79

Syms C (1995) Multi-scale analysis of habitat association in a guild of blennioid fishes. Mar Ecol Prog Ser 125:31-43

Syms C, Jones GP (1999) Scale of disturbance and the structure of a temperate fish guild. Ecology 80:921-940

Taylor RB (1998) Density, biomass and productivity of animals in four subtidal rocky reef habitats: the importance of small mobile invertebrates. Mar Ecol Prog Ser 172:37-51

Editorial responsibility: Otto Kinne (Editor),

Oldendorf/Luhe, Germany
Tegner MJ, Dayton PK (2000) Ecosystem effects of fishing in kelp forest communities. ICES J Mar Sci 57:579-589

Tolimieri N (1998) Contrasting effects of microhabitat use on large-scale adult abundance in families of Caribbean reef fishes. Mar Ecol Prog Ser 167:227-239

Townsend KA, Tibbetts IR (2000) Biomass and distribution of herbivorous blennies in the southern Great Barrier Reef. J Fish Biol 56:774-791

Tupper M, Boutilier RG (1997) Effects of habitat on settlement, growth, predation risk and survival of a temperate reef fish. Mar Ecol Prog Ser 151:225-236

Tupper M, Juanes F (1999) Effects of a marine reserve on recruitment of grunts (Haemulidae) at Barbados, West Indies. Environ Biol Fish 55:53-63

Wantiez L, Thollot P, Kulbicki M (1997) Effects of marine reserves on coral reef fish communities from five islands in New Caledonia. Coral Reefs 16:215-224

Weisberg S, Bingham C (1972) An approximate analysis of variance test for non-normality suitable for machine calculation. Technometrics 17:133-134

Willis TJ (2001) Visual census underestimates density and diversity of cryptic reef fishes. J Fish Biol 59:1408-1411

Willis TJ, Babcock RC (2000) A baited underwater video system for the determination of relative density of carnivorous reef fish. Mar Freshw Res 51:755-763

Willis TJ, Roberts CD (1996) Recolonisation and recruitment of fishes to intertidal rockpools at Wellington, New Zealand. Environ Biol Fish 47:329-343

Willis TJ, Millar RB, Babcock RC (2000) Detection of spatial variability in relative density of fishes: comparison of visual census, angling, and baited underwater video. Mar Ecol Prog Ser 198:249-260

Willis TJ, Millar RB, Babcock RC (2003) Protection of exploited fishes in temperate regions: high density and biomass of snapper Pagrus auratus (Sparidae) in northern New Zealand marine reserves. J Appl Ecol 40: $214-227$

Submitted: August 21, 2002; Accepted: April 29, 2003

Proofs received from author(s): July 22, 2003 